infusion has been the constant development of what appears to be an "inflammatory reaction" in the arm vein.

Studies in the clinical uses of prostaglandins are still at an early stage. Prostaglandin metabolites or derivatives may give even better results than the compounds available at present. A plea is made that in future a standard description of dose rate will be adopted- " $\mu \mathrm{g} / \mathrm{min}$ " seems simple and acceptable.

Rapid progress is being made, but the results reported here indicate that any future work on the uterus in late pregnancy must be very carefully monitored, by reliable measurement of amniotic fluid pressure, to detect any abnormal rise in uterine tone at the earliest possible moment.

We wish to thank Professor D. A. van Dorp, Vlaardingen, for the bulk of the supply of prostaglandins, and Dr. J. Pike, Upiohn Company. We also thank Mr. R. Marshall, Cardiff Royal Infirmary, for the illustrations, and the nursing staff of the department of obstetrics and gynaecology. Part of the work was carried out during the tenure of a United Cardiff Hospitals' Research Fellowship awarded to G.R.
References

Beazley, J. M., Dewhurst, C. J., and Gillespie, A. (1970). fournal of Obstetrics and Gynaecology of the British Commonwealth, 77, 193.

Bygdeman, M., Kwon, S. U., Mukherjee, T., and Wiqvist, N. (1968). American fournal of Obstetrics and Gynecology, 102, 317.

Caldeyro-Barcia, R., and Poseiro, J. J. (1958). International Congress of Gynaecology and Obstetrics, Montreal, p. 3.

Embrey, M. P. (1969). Fournal of Obstetrics and Gynaecology of the British Commonwealth, 76, 788 .

Embrey, M. P. (1970). British Medical fournal, 2, 256.

Embrey, M. P., and Anselmo, J. F. (1962). Fournal of Obstetrics and Gynaecology of the British Commonwealth, 69, 918 .

Embrey, M. P., and Morrison, D. L. (1968). Fournal of Obstetrics and Gynaecology of the British Commonwealth, 75, 829

Francis, J. G., Turnbull, A. C., and Thomas, F. F. (1970). Fournal of Obstetrics and Gynaecology of the British Commonwealth, 77, 594.

Karim, S. M. M., Hillier, K., Trussell, R. R., Patel, R. C., and Tamusange, S. (1970). Fournal of Obstetrics and Gynaecology of the British Commonwealth, 77, 200 .

Pickles, V. R., Hall, W. J., Best, F. A., and Smith, G. N. (1965). Fournal of Obstetrics and Gynaecology of the British Commonwealth, 72, 185

Roberts, G., Anderson, A., McGarry, J., and Turnbull, A. C. (1970). British Medical fournal, $2,152$.

Turnbull, A. C., and Anderson, A. B. M. (1968). Fournal of Obstetrics and Gynaecology of the British Commonwealth, 75, 24.

\title{
Blood Clotting and Platelet Aggregation during Oral Progestogen Contraception: a Follow-up Study
}

\author{
L. POLLER, JEAN M. THOMSON, WENDY THOMAS, CAROL WRAY
}

British Medical fournal, 1971, 1, 705-707

\section{Summary}

A two-year follow-up study of progestogen-only contraception with chlormadinone acetate indicates no increase of the level of factors VII and X, as found after three cycles with all oestrogen-progestogen oral contraceptives. Clotting factors which were raised with combined preparations became normal after the sixth monthly cycle of progestogen and remained normal during the two-year period of study.

From 12 months onwards significant changes in the thromboelastograph pattern were recorded, but not to the same extent as with combined preparations. At two years platelet aggregation was significantly accelerated with chlormadinone acetate but was not as rapid as with combined preparations.

\section{Introduction}

Oral contraception with conventional oestrogen-progestogen combinations produces significant increases in blood-clotting factors (Thomson and Poller, 1965; Poller et al., 1968) and in the rate of platelet aggregation after three months (Poller et al., 1969a). These changes were not found in women after progestogen-only contraception with chlormadinone acetate. Increased rates of blood clotting and platelet aggregation from oestrogen-progestogen combinations rapidly returned to normal when this progestogen was substituted (Poller et al.,

\footnotetext{
Department of Haematology, Withington Hospital, University Hospital of South Manchester, Manchester M20 8LR

L. POLLER, M.D., M.C.PATH., Consultant Haematologist JEAN M. THOMSON, F.I.M.L.T., Chief Research Assistant WENDY THOMAS, A.I.M.L.T., Senior Technician CAROL WRAY, B.sC., Research Assistant
}

1969b). Coagulation and thromboelastograph studies have been described up to the three-month stage of chlormadinone acetate administration and platelet aggregation to the sixmonth stage, but it was stated that a long-term study must be performed to exclude a delayed or cumulative action. The present study is a follow-up in the same group of women, tested at regular intervals over the first two years of continuous chlormadinone acetate administration.

\section{Method of study}

Follow-up studies have been performed at intervals of three months up to 18 months and again at two years. Initially women were divided into two groups as previously: group 1, those who had changed from combined preparations; and group 2, those who had not previously received oral contraceptives. From the six-month stage results of the two groups were pooled as they were shown to be identical from the coagulation standpoint. The details of collection and technical procedures were as previously described (Poller et al., $1969 \mathrm{a}, 1969 \mathrm{~b})$, except that the platelet aggregation studies were set up within 15 minutes of venepuncture.

The following tests were performed at each visit: prothrombin time, cephalin time, and factors VII and $\mathrm{X}$ assays. Platelet aggregation (Chandler's tube technique) and a quantitative fibrinogen assay (Ratnoff and Menzie, 1951) were repeated at the two-year stage only. The progestogen group was compared throughout with parallel groups of normal women. Results of the tests were recorded in seconds and not as percentages.

Thromboelastograph patterns were recorded in women in group 2 only-that is, those not previously on oral contraceptives. The following values were measured: " $r$ " (reaction time), "k" (thrombin phase), and "ma" (maximum amplitude). Statistical analysis was performed on these values and the results were analysed on a time basis. 


\section{Results}

Seventy-six women on continuous progestogen contraception, with chlormadinone acetate, were included in this study. They were not all started on this preparation together and new volunteers were added to the group under study at intervals over a period of 12 months. The study is still continuing but the second year figures are not yet complete. Twentyseven have now reached the 24-month stage. This number seemed large enough for an evaluation.

Coagulation Studies.-The prothrombin time and cephalin time of the progestogen group and controls showed no significant difference at any stage. Comparison of the two progestogen groups ( 1 and 2 ) at six months indicated that there was no difference at this time between those who had started on progestogen and those who had changed over from a combined preparation. Factor X levels, which our previous report showed were still significantly raised at three months in the group who had changed from combined preparations, became normal after six monthly cycles on chlormadinone acetate. Results of the two groups have therefore been combined from the six-month period. Factors VII and $\mathrm{X}$ results are given in Table I. Chlormadinone acetate has given no significant

TABLE I-Factors VII and $X$ Assays in the Chlormadinone Group and in Their Parallel Controls

\begin{tabular}{|c|c|c|c|c|c|c|c|c|c|}
\hline \multicolumn{5}{|c|}{$\begin{array}{l}\text { No. of Months on } \\
\text { Chlormadinone Acetate }\end{array}$} & \multirow{3}{*}{$\begin{array}{c}\begin{array}{c}\text { No. of } \\
\text { Women }\end{array} \\
27 \\
49\end{array}$} & \multicolumn{2}{|c|}{$\begin{array}{l}\text { Factor VII } \\
\quad(\mathrm{sec})\end{array}$} & \multicolumn{2}{|c|}{$\underset{\text { Factor } X}{\text { (sec) }}$} \\
\hline & & & & & & Mean & S.D. & Mean & S.D. \\
\hline $\begin{array}{ll}6 & (\text { group 1) } \\
6 & \text { (group 2) }\end{array}$ & $\begin{array}{l}\ldots \\
\cdots\end{array}$ & $\begin{array}{l}\cdots \\
\cdots\end{array}$ & $\therefore$ & $\begin{array}{l}\ldots \\
\cdots\end{array}$ & & $\begin{array}{l}18 \cdot 7 \\
19 \cdot 0\end{array}$ & $\begin{array}{l}1.4 \\
1.4\end{array}$ & $\begin{array}{l}18 \cdot 5 \\
18 \cdot 3\end{array}$ & $\begin{array}{l}1.1 \\
0.9\end{array}$ \\
\hline $\begin{array}{l}9 \\
\text { (Parallel controls) }\end{array}$ & . & $\cdots$ & $\because$ & $\begin{array}{l}\cdots \\
\cdots\end{array}$ & $\begin{array}{l}70 \\
70\end{array}$ & $\begin{array}{l}19 \cdot 7 \\
19 \cdot 8\end{array}$ & $\begin{array}{l}1.4 \\
1 \cdot 3\end{array}$ & $\begin{array}{l}17 \cdot 9 \\
18 \cdot 1\end{array}$ & $\begin{array}{l}1 \cdot 5 \\
1 \cdot 2\end{array}$ \\
\hline $\begin{array}{l}12 \\
\text { (Parallel controls) }\end{array}$ & $\begin{array}{l}\ldots \\
\cdots\end{array}$ & $\cdots$ & $\because$ & 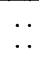 & $\begin{array}{l}64 \\
64\end{array}$ & $\begin{array}{l}19 \cdot 4 \\
19 \cdot 3\end{array}$ & $\begin{array}{l}1 \cdot 4 \\
1 \cdot 1\end{array}$ & $\begin{array}{l}17 \cdot 9 \\
18 \cdot 1\end{array}$ & $\begin{array}{l}1.5 \\
1.2\end{array}$ \\
\hline $\begin{array}{l}15 \\
\text { (Parallel controls) }\end{array}$ & $\begin{array}{l}\cdots \\
\cdots\end{array}$ & $\therefore$ & $\because$ & $\because$ & $\begin{array}{l}54 \\
54\end{array}$ & $\begin{array}{l}19 \cdot 2 \\
19 \cdot 0\end{array}$ & $\begin{array}{l}1.3 \\
0.8\end{array}$ & $\begin{array}{l}17 \cdot 6 \\
17 \cdot 6\end{array}$ & $\begin{array}{l}1 \cdot 4 \\
1 \cdot 3\end{array}$ \\
\hline $\begin{array}{l}18 \\
\text { (Parallel controls) }\end{array}$ & $\begin{array}{l}\ldots \\
\cdots\end{array}$ & 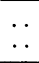 & $\because$ & $\therefore$ & $\begin{array}{l}34 \\
34\end{array}$ & $\begin{array}{l}18 \cdot 7 \\
18 \cdot 3\end{array}$ & $\begin{array}{l}1 \cdot 3 \\
1 \cdot 1\end{array}$ & $\begin{array}{l}15 \cdot 5 \\
15 \cdot 8\end{array}$ & $\begin{array}{l}1.3 \\
1 \cdot 1\end{array}$ \\
\hline$\underset{\text { (Parallel controls) }}{24}$ & . & 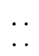 & .. & $\because$ & $\begin{array}{l}27 \\
27\end{array}$ & $\begin{array}{l}19 \cdot 6 \\
18 \cdot 9\end{array}$ & $\begin{array}{l}1 \cdot 6 \\
1.0\end{array}$ & $\begin{array}{l}16 \cdot 8 \\
16 \cdot 4\end{array}$ & $\begin{array}{l}1.7 \\
1.7\end{array}$ \\
\hline
\end{tabular}

change in factor VII and factor $\mathrm{X}$ assays over the two-year period. The fibrinogen level was also normal at two years.

Thromboelastographic Studies.-Detailed results are given in Table II. The $\mathbf{r}$ time became significantly shortened

TABLE II-Thromboelastogram values during Chlormadinone Acetate Administration

\begin{tabular}{|c|c|c|c|c|c|c|c|c|c|c|}
\hline \multirow{2}{*}{\multicolumn{2}{|c|}{$\begin{array}{l}\text { No. of } \\
\text { Months on } \\
\text { Chlormadi- } \\
\text { none Acetate }\end{array}$}} & \multirow{2}{*}{$\begin{array}{l}\text { No. of } \\
\text { Women }\end{array}$} & \multicolumn{2}{|c|}{$\mathbf{r}$} & \multicolumn{2}{|c|}{$\mathbf{r}+\mathbf{k}$} & \multicolumn{2}{|c|}{ k } & \multicolumn{2}{|c|}{$\mathrm{ma}$} \\
\hline & & & $\begin{array}{l}\text { Mean } \\
(\mathrm{mm})\end{array}$ & S.D. & $\begin{array}{l}\text { Mean } \\
(\mathrm{mm})\end{array}$ & S.D. & $\begin{array}{l}\text { Mean } \\
(\mathrm{mm})\end{array}$ & S.D. & $\begin{array}{l}\text { Mean } \\
(\mathrm{mm})\end{array}$ & S.D. \\
\hline $\begin{array}{r}0 \\
3 \\
6 \\
12 \\
15 \\
18 \\
24\end{array}$ & $\begin{array}{l}\ldots \\
\cdots \\
\cdots \\
\cdots \\
\cdots \\
\cdots\end{array}$ & $\begin{array}{l}18 \\
12 \\
11 \\
18 \\
17 \\
29 \\
15\end{array}$ & $\begin{array}{l}14 \cdot 1 \\
14 \cdot 0 \\
13 \cdot 6 \\
13 \cdot 0 \\
11 \cdot 4 \\
10 \cdot 6 \\
11 \cdot 1\end{array}$ & $\begin{array}{l}1.3 \\
1.4 \\
1.7 \\
0.4 \\
3.0 \\
2.7 \\
2.8\end{array}$ & $\begin{array}{l}21 \cdot 6 \\
21 \cdot 0 \\
21 \cdot 0 \\
20.6 \\
18 \cdot 1 \\
17.0 \\
18 \cdot 2\end{array}$ & $\begin{array}{l}1.2 \\
2.6 \\
3.9 \\
3.4 \\
3.9 \\
4.0 \\
3.8\end{array}$ & $\begin{array}{l}7 \cdot 5 \\
6 \cdot 9 \\
7 \cdot 5 \\
7 \cdot 3 \\
6 \cdot 1 \\
6 \cdot 1 \\
7 \cdot 1\end{array}$ & $\begin{array}{l}1.2 \\
1.5 \\
0.8 \\
1.4 \\
1.6 \\
1.4 \\
1.7\end{array}$ & $\begin{array}{l}50 \cdot 0 \\
50 \cdot 5 \\
50 \cdot 0 \\
48 \cdot 5 \\
48 \cdot 8 \\
50 \cdot 3 \\
47 \cdot 5\end{array}$ & $\begin{array}{l}4.2 \\
3.8 \\
3.9 \\
1.4 \\
5.7 \\
5.8 \\
5.1\end{array}$ \\
\hline
\end{tabular}

from 12 months onwards. The combined $r+k$ time, which is believed to be equivalent to the plasma-clotting time, became significantly shortened from 15 months. The maximum amplitude showed no change over the two-year period of study.

Platelet Aggregation Studies.-The platelet aggregation results at the two-year stage compared with the parallel normals are given in Table III. Progestogen-only contraception produced a significantly increased rate of platelet aggregation in Chandler's tube technique when compared with the normal group.
TABLE III-Platelet Aggregation after Chlormadinone Acetate Administration, Compared with Parallel Controls

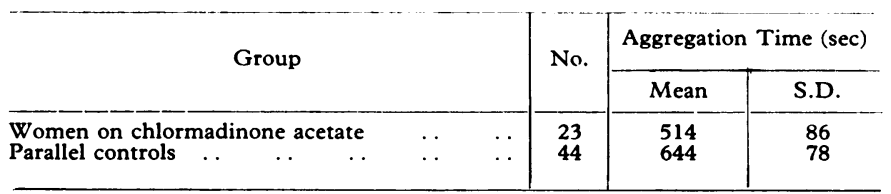

\section{Discussion}

In the previous report no adverse effect on clotting factors or platelet aggregation was found during the first months of administration of chlormadinone acetate. It was stated, however, that long-term follow-up was necessary to exclude a delayed or cumulative effect. After two years on the progestogen the same women have shown no acceleration of their clotting tests. In this respect the results with chlormadinone acetate are encouraging. On the other hand, there is an alteration of the thromboelastograph tracing and an increase in the rate of platelet aggregation with long-term administration.

The discovery of accelerated platelet aggregation after two years on the progestogen is a worrying feature, but some reassurance may be obtained from a parallel study which is in progress on combined oestrogen-progestogen preparations. The increased rate of platelet aggregation recorded in our progestogen groups is still significantly less than with the combined preparations.

The thromboelastograph studies were available only in the group who had not previously taken an oral contraceptive preparation. Thromboelastography gives a measure of overall "intrinsic" clotting, platelet function, and fibrinolysis. The findings are therefore non-specific but do confirm the trend towards "hypercoagulability." Like the changes in platelet aggregation, alterations in thromboelastograph patterns are proving to be less pronounced than in our concurrent longterm study of combined oestrogen-progestogen preparations. With combined preparations the maximum amplitude value (ma) also is increased. This increase in $\mathrm{ma}$, in addition, occurs with venous thrombosis and postexercise hypercoagulability (Poller et al., 1971).

It is interesting to speculate on the reasons for the discrepant findings in the coagulation tests and platelet aggregation. The platelet-clotting system involved in Chandler's tube platelet aggregation is believed to require smaller amounts of thrombin than the blood-clotting mechanism, and it is possible, therefore, that the technique may pick out acceleration of clotting before it can be detected by coagulation tests. Alternatively, the changes in Chandler's tube may be a specific effect on platelet aggregation not reflected in the coagulation tests. The return of platelet aggregation to normal occurs much quicker than the reversal of the altered levels of clotting factors, suggesting that the mechanism may not be simply related to measurable amounts of clotting factors in the blood.

\section{Conclusion}

Chlormadinone acetate may be an advance on conventional oestrogen-progestogen oral contraception. Effects on clotting factors have not been recorded with up to two years' administration. Platelet aggregation changes appear later and are significantly less pronounced than with combined preparations. Thromboelastograph patterns are not as abnormal as with combined oral contraception. Further follow-up is required to establish whether the increased rate of platelet aggregation and altered thromboelastograph patterns become more abnormal. It is interesting to speculate on the reason 
for delayed alteration in platelet aggregation and thromboelastography. This may result from the body's adjustment to large amounts of exogenous progestogen. It is also important to determine whether these less pronounced changes are reflected in significantly diminished risk of clinical thrombosis. This will have to be demonstrated by clinical study, assuming that the drug again becomes generally available.

The absence of any rise in clotting factors and the fact that raised clotting factors from combined preparations returned to normal and remained normal over the two-year period of study are encouraging features of progestogen-only contraception with chlormadinone acetate.

The work was performed while in receipt of a grant for thrombosis research from the Manchester Regional Hospital Board and from Syntex Pharmaceuticals Limited, who also supplied the chlormadinone acetate (Normenon).

\section{References}

Poller, L., Tabiowo, Anne, and Thomson, Jean M. (1968). British Medical

Journal, 3, 218.
Poller, L., Priest, Celia M., and Thomson, Jean M. (1969a). British Medical Fournal, 4, 273.

Poller, L., Thomson, Jean M., Tabiowo, Anne, and Priest, Celia M. (1969b). British Medical fournal, 1, 554.

Poller, L., Priest, Celia M., and Thomson, Jean M. (1971). Journal of Physiology. To be published.

Ratnoff, O. D., and Menzie, C. (1951). Fournal of Laboratory and Clinical Medicine, 37, 316 .

Thomson, Jean M., and Poller, L. (1965). British Medical fournal, 2, 270.

\title{
Effect of Aspirin on Renal Clearance of ${ }^{125}$ I-Diatrizoate
}

\author{
LINDA BEELEY, M. J. KENDALL
}

British Medical fournal, 1971, 1, 707-708

\section{Summary}

Glomerular filtration rate was measured from the plasma disappearance curve after a single injection of sodium ${ }^{125} I$-diatrizoate. A therapeutic dose of aspirin in 13 subjects produced a mean fall in glomerular filtration rate of $10.5 \%$.

\section{Introduction}

Prolonged consumption of analgesic drugs is known to impair renal function (Nanra and Kincaid-Smith, 1970) but the acute effects of these drugs are unknown. Conventional methods for assessing glomerular filtration are either tedious to perform or too inaccurate to detect short-lived changes in renal function. Recent papers (Chantler, Garnett, Parsons, and Veall, 1969) have suggested that a single-injection technique by which renal clearance is calculated from the plasma disappearance of a radioactive substance correlates well with inulin clearance and is highly reproducible. We have therefore used the clearance of sodium ${ }^{125}$ I-diatrizoate (Hypaque) to study the acute effects of aspirin on glomerular filtration rate.

\section{Patients and Methods}

Fifteen medical inpatients were studied. All were informed of the nature and purpose of the studies and gave their consent. None had any impairment of renal function and all patients were in a steady state. All studies were performed at the same time of day and under the same conditions.

For the measurement of clearance a dose of radioactive Hypaque of approximately $0.4 \mu \mathrm{Ci} / \mathrm{kg}$ body weight was prepared in a 1-ml syringe and calculated accurately by weighing on a Mettler balance. About one-fifth of the dose was similarly weighed, diluted in a litre of water, and used as

Queen Elizabeth Hospital, Birmingham 15

LINDA BEELEY, M.A., M.R.C.P., Registrar, Department of Medicine M. J. KENDALL, M.R.C.P., Research Fellow a standard. The dose was diluted in $5 \mathrm{ml}$ of saline and given intravenously. Blood samples were taken at intervals and centrifuged, and the plasma was assayed for radioactivity, together with the standard, in a well-type scintillation counter. The results were used to plot the plasma disappearance curve of the injected Hypaque on a semilogarithmic scale (see Chart). Like other investigators (Denneberg, 1965), we found that after the intravenous administration of a single dose of labelled Hypaque the plasma activity falls off rapidly at first, but after one and a half to two hours the graph of plasma activity against time approximates closely to a single exponential curve. Three blood samples were therefore takenat two, three, and four hours after the injection of Hypaque.

For the calculation of plasma clearance the final part of the curve was extrapolated back to zero time to obtain the effective initial activity of the plasma (a). The theoretical volume of distribution $(\mathrm{V})$ is then given by:

$$
\mathrm{V}=\frac{\text { Dose }}{\mathrm{a}}
$$

The actual dose injected was obtained from:

$$
\text { Dose }=\frac{\text { weight of dose }}{\text { weight of standard }} \times \text { activity of standard. }
$$

The half-time of the linear part of the curve was measured and the slope constant $(\lambda)$ obtained from:

$$
\lambda=\frac{\log _{e} 2}{T_{t}}
$$

The plasma clearance is then given by $V \lambda$.

In each subject we measured Hypaque clearance before and after a single dose of aspirin. For the aspirin experiments we gave $20 \mathrm{mg} / \mathrm{kg}$ body weight (3-6 tablets of soluble aspirin) at the same time as the injection of Hypaque, and the two determinations on each patient were done on consecutive days.

\section{Results}

In 2 of the 15 patients the results did not fall on a straight line and could therefore not be used for measuring clearance. 